\title{
Natural Polysaccharide-Based Gels for Dairy Food Preservation
}

\author{
P. Laurienzo, ${ }^{*}$ M. Malinconico, ${ }^{* 1}$ R. Pizzano, $†$ C. Manzo, $†$ N. Piciocchi, $\uparrow$ A. Sorrentino, $†$ and M. G. Volpe \\ *Istituto di Chimica e Tecnologia dei Polimeri, C.N.R., Via Campi Flegrei, 34 - Pozzuoli (Naples), Italy \\ †Istituto di Scienze dell'Alimentazione, C.N.R., Via Roma, 52 - Avellino, Italy
}

\section{ABSTRACT}

The innovative packaging systems described in the present work, based on natural gels, have been shown to increase the shelf life of the Mozzarella cheese, without adding any chemical substance and without thermal procedures. Physical, physicochemical, microbiological, analytical, and mechanical analyses were used to monitor the quality of the cheese as a function of storage type and storage time. In particular, microbiological analysis confirmed that the characteristics of the Mozzarella cheese stored at $4^{\circ} \mathrm{C}$ in gel are maintained for more than $15 \mathrm{~d}$, whereas samples stored in the mother solution lost important characteristics after $5 \mathrm{~d}$. A penetration test (texture) confirmed that the Mozzarella cheese preserved in the gel maintained mechanical properties similar to those of the fresh product, even after storage for $30 \mathrm{~d}$ at $4^{\circ} \mathrm{C}$.

Key words: natural polysaccharide, food preservation, gels

\section{INTRODUCTION}

Water buffalo Mozzarella cheese is a typical "pasta filata" cheese from Southern Italy, with high moisture (55 to $62 \%$ ) and a high fat ( $>45 \%$ ) content, characterized by a soft body and a juicy appearance, and by a pleasant, fresh, sour, and slightly nutty flavor. The manufacture of this cheese has been described in detail in the literature (Coppola et al., 1988, 1990; Ercolini et al., 2004). Briefly, the cheese is made from whole, raw water buffalo milk by adding a natural whey culture (from the manufacture of the previous day) as a starter (Salvatori del Prato, 1998). After a curd-ripening phase (4.0 to 4.5 $\mathrm{h}$ at 35 to $37^{\circ} \mathrm{C}$ ), the optimal $\mathrm{pH}$ (4.9 to 5.1) is reached, and the drained curd is stretched in hot water (90 to $95^{\circ} \mathrm{C}$ ). Water buffalo Mozzarella cheese from Campania (Mozzarella di Bufala Campana) received European Product of Designated Origin (DOP, EEC, 1996; Regulation no. 1107 of Jun 12, 1996) certification, and has represented, for many years, a winning product of

Received January 25, 2006.

Accepted March 7, 2006.

${ }^{1}$ Corresponding author: mario.malinconico@ictp.cnr.it southern Italy. In 2001, a $5.1 \%$ increase in sales of quality Mozzarella (so-called DOP Mozzarella) were recorded. In 2002, sales of quality cheese fell $1.6 \%$, but sales of DOP Mozzarella increased $7 \%$. In fact, there is increasing consumer demand for water buffalo Mozzarella cheese. The same market research has shown that Mozzarella is not consumed in northern countries as much as it should; this situation can be partly attributed to a lack of cultural knowledge, but mainly to the very limited shelf life of this cheese. The shelf life of Mozzarella is strictly linked to the type of raw material used (unpasteurized milk), and to the technology of processing. The product obtained from unpasteurized milk and natural whey can be stored, immersed in its mother solution, for 3 to $4 \mathrm{~d}$ at a temperature between 4 and $10^{\circ} \mathrm{C}$ with no loss of its characteristics (translucent external skin, white color, soft and elastic curd, peculiar taste of fresh milk, and wildness aroma; Paonessa, 2004). Beyond this period, the external skin peels off and the shred loses consistency and becomes buttery following the destruction of the overlapping shell structure obtained during high-temperature stretching. Only industrial products, made with pasteurized milk and selected starter, can maintain a prolonged shelf life, up to $20 \mathrm{~d}$, but the taste is unsatisfactory when compared with traditional, artisanal Mozzarella. Currently, the packaging of Mozzarella consists of rigid or flexible films of multilayer material, packages made of polyethylene/paper laminated films or, more recently, tetrapack-type packages (Robertson, 1993). None of these packages solves the problems of the limited shelf life of real water buffalo Mozzarella cheese. Today, many researchers focus on the development of new methodologies and innovative materials that increase the shelf life of foods. The basis of the innovation is primarily related to the choice of material: mixtures of biodegradable and biocompatible polymers belonging to well-known families of natural polysaccharides already approved for use in agri-food industry. Such biopolymers represent the widest fraction of organic matter present on the planet, and include cellulose, starch, and chitin. It is relevant to note that such biopolymers are highly stereoregular macromolecules, hydrophilic, reactive, and able to exhibit biological "intelligence" similar to that of the more celebrated biopolymers such as 
proteins and nucleic acids. Consequently, many polysaccharides, being available in enormous amounts and with a wide range of chemical and physical behaviors, either in bulk, in solution, or in gel state, represent an unsubstitutable commodity. Finally, many polysaccharides adapt well to the formulation of biocompatible and biodegradable polymeric materials, an application whose demand is rapidly increasing in different sectors, from agri-food to pharmaceutical (Peterson et al., 1999). The aim of our research was to develop innovative packaging systems for traditional Mozzarella that would be able to guarantee prolonged shelf life of at least $15 \mathrm{~d}$, with no influence on the production methodology and no influence on the taste, mechanical properties, and nutritional properties of the product. In this paper, we report on the main results of our research, which include evaluation of $\mathrm{pH}$, microbiological analysis, electrophoretic analysis, and mechanical tests as function of type of storage medium and storage time.

\section{MATERIALS AND METHODS}

\section{Gel Preparation}

All the polysaccharides used were FDA approved. Although a process of patenting is under evaluation, the main characteristic of the mixture is the prevalence ( $80 \%$ at least) of polysaccharides whose water solutions are able to form a gel at temperature below $20^{\circ} \mathrm{C}$. Agarose and gellan are typical components of the mixture. Before formation of the gel, at a temperature of about $40^{\circ} \mathrm{C}$, the cheese is immersed into the solution and the gel sets at room temperature $\left(20^{\circ} \mathrm{C}\right)$; the packed cheese can then be stored as usual at a temperature between 4 and $8^{\circ} \mathrm{C}$.

\section{pH Measurements}

$\mathrm{pH}$ determinations were carried out using a Crison model $507 \mathrm{pH}$ meter equipped with type 52-00 electrodes and a type 52-32 electrode (Crison Instruments, Barcelona, Spain) for penetration analysis.

\section{Microbiological Analyses}

Cheese samples (10 g) were homogenized with $90 \mathrm{~mL}$ of sterile Ringer solution (Oxoid, Basingstoke, UK) in a stomacher 400 (Lab Blender, Seward Medical, London, UK), and serially diluted in the same diluent. Different dilutions were plated on specific growth media (all from Oxoid) and the colonies were counted after incubation. The total mesophilic microflora was determined on plate count agar incubated at $30^{\circ} \mathrm{C}$ for $72 \mathrm{~h}$. Mesophilic and thermophilic lactic acid bacteria were determined on de Man, Rogosa, and Sharpe agar incubated in an- aerobic conditions using jars with a gas-generating kit (Oxoid, Basingstoke, UK) at 28 and $45^{\circ} \mathrm{C}$ for $48 \mathrm{~h}$, respectively. Lactococci and streptococci were enumerated by plating onto M17 agar and incubating at 22 and $44^{\circ} \mathrm{C}$ for 48 to $72 \mathrm{~h}$. Enterococci were counted on Slanetz and Bartley agar incubated at $37^{\circ} \mathrm{C}$ for $48 \mathrm{~h}$. Total coliforms were plated onto violet red bile glucose agar and incubated at $37^{\circ} \mathrm{C}$ for $48 \mathrm{~h}$. Fecal coliforms were counted by pouring onto plates with violet red bile lactose agar followed by incubation at $44^{\circ} \mathrm{C}$ for $48 \mathrm{~h}$. Yeasts were enumerated on yeast peptone dextrose agar (10 g/L yeast extract; $20 \mathrm{~g} / \mathrm{L}$ peptone; $20 \mathrm{~g} / \mathrm{L}$ dextrose; $20 \mathrm{~g} / \mathrm{L}$ agar) and incubated at $30^{\circ} \mathrm{C}$ for $5 \mathrm{~d}$.

\section{Whole Casein Collection from Milk}

Water buffalo milk was drawn from a local private herd according to sanitary regulations. Fat was removed from the freshly sampled milk by centrifugation at $3,900 \times g$ for $10 \mathrm{~min}$ at $4^{\circ} \mathrm{C}$. Whole casein was obtained from defatted milk by isoelectric precipitation at $\mathrm{pH} 4.6$ according to the currently used procedure (Pizzano et al., 1998). The pellet was suspended in water, $\mathrm{pH}$ was brought to neutrality with $2 \mathrm{~N} \mathrm{NaOH}$, and the casein solution was lyophilized.

\section{Protein Collection from Mozzarella Cheese Samples}

The water buffalo Mozzarella cheese samples were supplied by a local factory. Cheese samples (500 mg) were suspended in $50 \mathrm{~mL}$ of $50 \mathrm{~m} M$ ammonium bicarbonate, $\mathrm{pH}$ 8.5, and homogenized with an Ultra-Turrax blender (model T25, IKA Labortechnik, Staufen, Germany) at 12,000 rpm for $2 \mathrm{~min}$ at room temperature. After gentle mixing in a rotating device for 10 to $12 \mathrm{~h}$ at $4^{\circ} \mathrm{C}$, each suspension was centrifuged at $3,900 \times g$ for $10 \mathrm{~min}$ at $4^{\circ} \mathrm{C}$, and fat was manually removed from the cheese solution surface. The liquid phase containing the whole cheese protein fraction was freeze-dried for electrophoresis. A similar procedure including defatting was carried out to obtain the $\mathrm{pH} 4.6$-soluble and $\mathrm{pH}$ 4.6-insoluble cheese protein subfractions. After fat removal, the $\mathrm{pH}$ of the liquid phase was brought to 4.6 by adding $1 \mathrm{M} \mathrm{HCl}$ under $\mathrm{pH}$ meter control. The resulting suspension was centrifuged at $3,900 \times g$ for $20 \mathrm{~min}$. The supernatant, containing the $\mathrm{pH} 4.6$-soluble protein subfraction of the cheese sample, was carefully removed with a Pasteur pipette from the tube containing the pellet (the $\mathrm{pH}$ 4.6-insoluble subfraction). The 2 protein subfractions were freeze-dried for electrophoresis and reverse phase-HPLC (RP-HPLC) analysis. 


\section{Electrophoretic Analysis}

Isoelectric focusing on thin-layer $(0.25 \mathrm{~mm})$ polyacrylamide gel (PAGIF) was carried out as described by Trieu-Cuot and Gripon (1981). The $\mathrm{pH}$ gradient in the range 2.5 to 6.5 was obtained by mixing Ampholine (Pharmacia, Uppsala, Sweden) 2.5-5, 4.5-5.4, and 46.5 in the ratio $1.6: 1.4: 1$ ( $\mathrm{vol} / \mathrm{vol} / \mathrm{vol})$. The gel was stained with Coomassie Brilliant Blue G-250 according to the procedure described by Blakesley and Boezi (1977). Vertical PAGE (disc-PAGE) in presence of 6.1 $M$ urea was carried out at $\mathrm{pH} 8.6$ as described by Chianese et al. (1992). An 8-mg aliquot from the dry protein pellets obtained as described above was dissolved in $0.2 \mathrm{~mL}$ of $8 M$ urea solution containing $143 \mathrm{mM}$ 2mercaptoethanol. A 5- $\mu \mathrm{L}$ aliquot of each protein solution (either whole proteins, $\mathrm{pH} 4$ 4.6-soluble fraction, or $\mathrm{pH}$ 4.6-insoluble fraction) was loaded onto a thin-layer polyacrylamide gel for isoelectric focusing analysis. The same solutions, after addition of glycerol to a final concentration of $30 \%$ (vol/vol), were used as cheese samples in PAGE at $\mathrm{pH}$ 8.6.

\section{RP-HPLC Analysis of the $\mathrm{pH}$ 4.6-Soluble Fraction}

The $\mathrm{pH} 4.6$-soluble fraction of cheese samples was redissolved in $2 \mathrm{~mL}$ of water and filtered through a $0.45-\mu \mathrm{m}$ filter (Millipore, Bedford, MA). A 100- $\mu \mathrm{L}$ aliquot was loaded onto a C18 column $(10 \times 250 \mathrm{~mm}, 10$ $\mu \mathrm{m}$ ) from Vydac (Hesperia, CA) equilibrated with $0.1 \%$ trifluoracetic acid in water (solution $\mathrm{A}$ ) at a flow rate of $2.5 \mathrm{~mL} / \mathrm{min}$. Chromatography was performed using a Kontron HPLC equipment (Kontron Instruments, Milan, Italy), consisting of 2 model 420 pumps, a Rheodyne sample injector, and a model 491 solvent programmer. Elution was followed at $220 \mathrm{~nm}$ using a Kontron variable-wavelength detector (model 430). The mobile phase was obtained by mixing solvent $\mathrm{A}$ and $0.07 \%$ trifluoroacetic acid in acetonitrile (solvent B). After a 10-min hold at $0 \%$ solvent B, elution was performed by a linear gradient from 0 to $60 \% \mathrm{~B}$ over $30 \mathrm{~min}$.

\section{Mechanical Properties}

The evaluation of mechanical properties was evaluated by compressive tests. The samples of Mozzarella (spheres, diameter: $5 \pm 0.5 \mathrm{~cm}$ ) were subjected to texturometric tests by monoaxial compression (Vernon and Sherman, 1978; Masi and Addeo, 1984). The samples were put in a cylindrical plastic container (diameter: 6 $\mathrm{cm}$ ), and a spherical dart, mounted on the mobile gauge of an Instron model 4301 apparatus (Instron, Norwood, MA), was moved into the cheese sample to $2.5 \mathrm{~cm}$ at a constant speed of $1 \mathrm{~cm} / \mathrm{min}$. The force needed to pene- trate into the cheese was recorded against the displacement.

\section{Testing Procedure}

It was first necessary to determine the optimal concentration of polysaccharides in water to achieve a gel of sufficient strength; that is, a compact gel with no tendency to leave residues when opened. We investigated, at fixed gel composition, a concentration of polysaccharides in water range from 0.5 to $1.5 \%$ by weight; it was found that the upper limit, $1.5 \%$, produced a gel that did not leave any residue around the cheese when opened. Above this concentration, it was hard to control the rate of gelation (gelation became too rapid). There was evidence that a gel that was too tight would not allow the release of enough water to the surface of the cheese, resulting in dryness of the cheese. Once the best concentration was chosen, the second parameter to be adjusted was the storage temperature of the cheese. The 2 procedures used differed in the storage temperature of the first $5 \mathrm{~d}$ of storage $\left(18 \mathrm{vs} .4^{\circ} \mathrm{C}\right)$; after $5 \mathrm{~d}$, all packages were stored in a refrigerator at $4^{\circ} \mathrm{C}$ up to $20 \mathrm{~d}$. This is because some producers suggest keeping Mozzarella at room temperature for the first 3 to $4 \mathrm{~d}$. As a reference, we used a Mozzarella cheese of the same production batch, stored in the same environmental conditions, in its own preservation liquid.

The tests carried out on the cheeses at different storage time and relative control were as follows: 1) visual inspection and comparison of the 2 sets of products (color, odor, compactness, elasticity, presence of milk drop); 2) microbiological analysis; 3) $\mathrm{pH}$ measurements of sample and control, and of their storage systems (gel and liquid); and 4) compression tests.

\section{RESULTS AND DISCUSSION}

\section{Visual Inspection}

In the first experimental protocol, all samples and control were stored for $5 \mathrm{~d}$ at $18^{\circ} \mathrm{C}$ and thereafter in a refrigerator at $4^{\circ} \mathrm{C}$. After this first period, visual and microbiological analyses were affected. On visual inspection, there was a strong difference of the gel-stored cheese compared with the control: the curd was still soft and elastic, and when cut, the typical milk drop was observed. The odor, although initially less evident, became the typical wild, slightly aromatic odor of fresh cheese after few minutes. The control, as expected, had already become softer and had a slightly slimy external surface. Although the obtained results were encouraging, we noted that the gel-stored Mozzarella did not exhibit exactly the appearance and the properties of the fresh cheese. A new set of experiments was then 


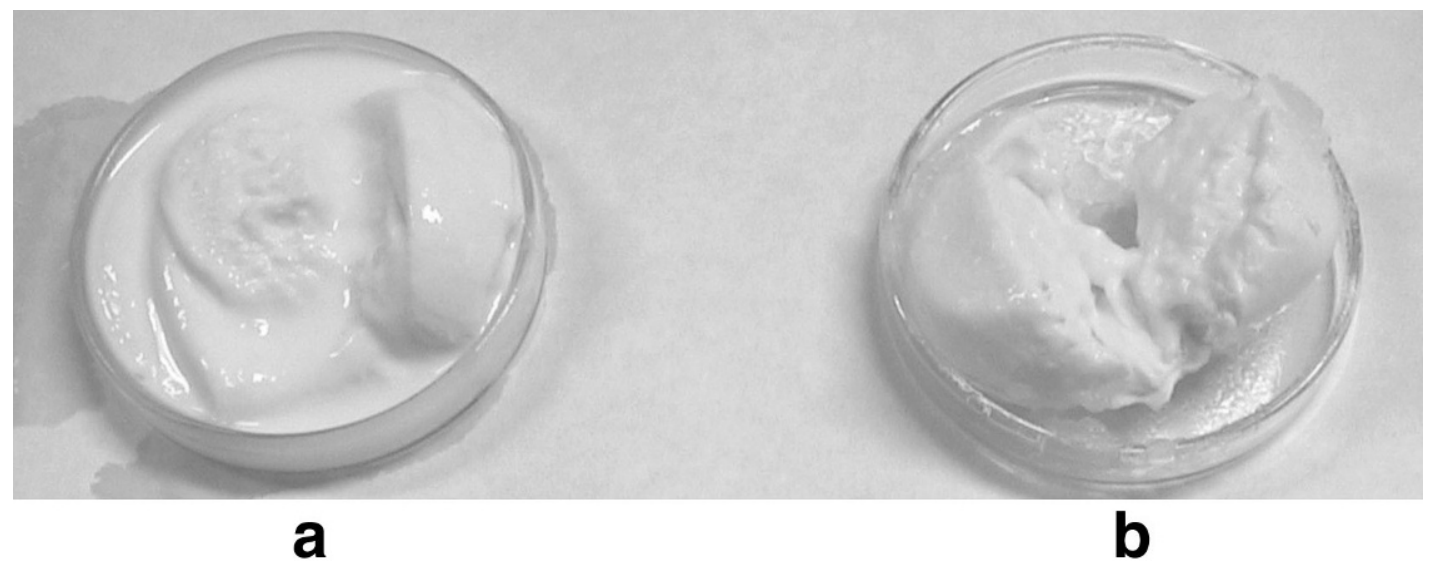

Figure 1. Water buffalo Mozzarella cheese stored in preservation liquid (a) and in gel (b) at $4^{\circ} \mathrm{C}$ for $20 \mathrm{~d}$.

planned, storing the as-prepared samples in a refrigerator at $4^{\circ} \mathrm{C}$.

The differences between the 2 packaging methods were already evident after $5 \mathrm{~d}$ of storage. The gel-stored cheese was dense, elastic, with typical milk drop; and the internal curd was granular and soft. The liquidstored cheese showed a rather translucent and slightly slimy surface; and the internal pasta was buttery and weak with low persistency of the typical aroma. As previously noted, we observed that the surface of the gel-stored cheese looked dry initially, but recovered its humidity after a few minutes. Again, the characteristic odor was initially less evident upon opening, but after a few minutes, it was possible to smell the typical wild aroma of water buffalo Mozzarella.

A second evaluation was carried out after $10 \mathrm{~d}$ of storage. The differences were even more evident in favor of the gel-stored cheese, which maintained its original characteristics. In the control, on the contrary, the degradation processes became more evident: the surface was slimier and the curd lost its dense and layered structure.

After $15 \mathrm{~d}$, the gel-stored cheese showed results even more surprising in the differences between the control (very slimy surface, typical odor of butter, weak curd) and the sample (very good compactness, elastic pasta, granular internal curd, and typical milk drop when finger squeezed). The test was extended to $20 \mathrm{~d}$, and the differences between gel-stored and control cheeses were maintained (Figure 1).

\section{Microbiological Analysis}

The evolution of microflora isolated from water buffalo Mozzarella cheese stored in preservation liquid (M) and in innovative gel (MA) is shown in Figures 2 and 3.
The water buffalo Mozzarella cheese was stored after packaging at $18^{\circ} \mathrm{C}$ for $5 \mathrm{~d}$ (Figure 2) to evaluate the effects of temperature and media composition on natural microbial growth. The counts of the different groups of microorganisms, isolated from the water buffalo Mozzarella cheese before packaging (samples $\mathrm{M}$ and MA), were in the range from 2 to $6 \log _{10} \mathrm{cfu} / \mathrm{g}$. There was an increase of $3 \log _{10} \mathrm{cfu} / \mathrm{g}$ for total mesophilic microflora, lactic acid bacteria, and enterococci, whereas there was an increase of around $1.5 \log _{10} \mathrm{cfu} / \mathrm{g}$ for the yeasts, total coliforms, and fecal coliforms. Thus, storage of water buffalo Mozzarella cheese at room temperature was not advised, because it promoted an increase of natural microflora.

In Figure 3, the counts of natural microflora isolated from the samples stored at $4^{\circ} \mathrm{C}$ for 5,10 , and $15 \mathrm{~d}$ are illustrated. In the cheese stored in preservation liquid, the total mesophilic microflora and lactic acid bacteria shows a higher increase than the Mozzarella stored in the experimental gel. Enterococci revealed a different ability of growth in the samples (M and MA); in particular, they were not able to grow in the gel. The innovative gels based on natural polysaccharides established an unfavorable habitat for the growth of natural microflora, and enterococcal flora in particular.

\section{Determination of $\mathrm{pH}$}

The $\mathrm{pH}$ was measured on both cheeses at the beginning of the tests and at regular intervals throughout; the values are reported in Table 1 . In general we noticed, in the case of the liquid medium, a trend of $\mathrm{pH}$ to change from more acidic to more alkaline values over $20 \mathrm{~d}$ of storage (from 4.28 up 5.00). Cheeses stored in such liquid showed a slight increase of $\mathrm{pH}$ from $\mathrm{d} 0$ (5.25) to $d 10$ (5.42), whereas the values recorded at $d$ 20 were lower (5.02). 


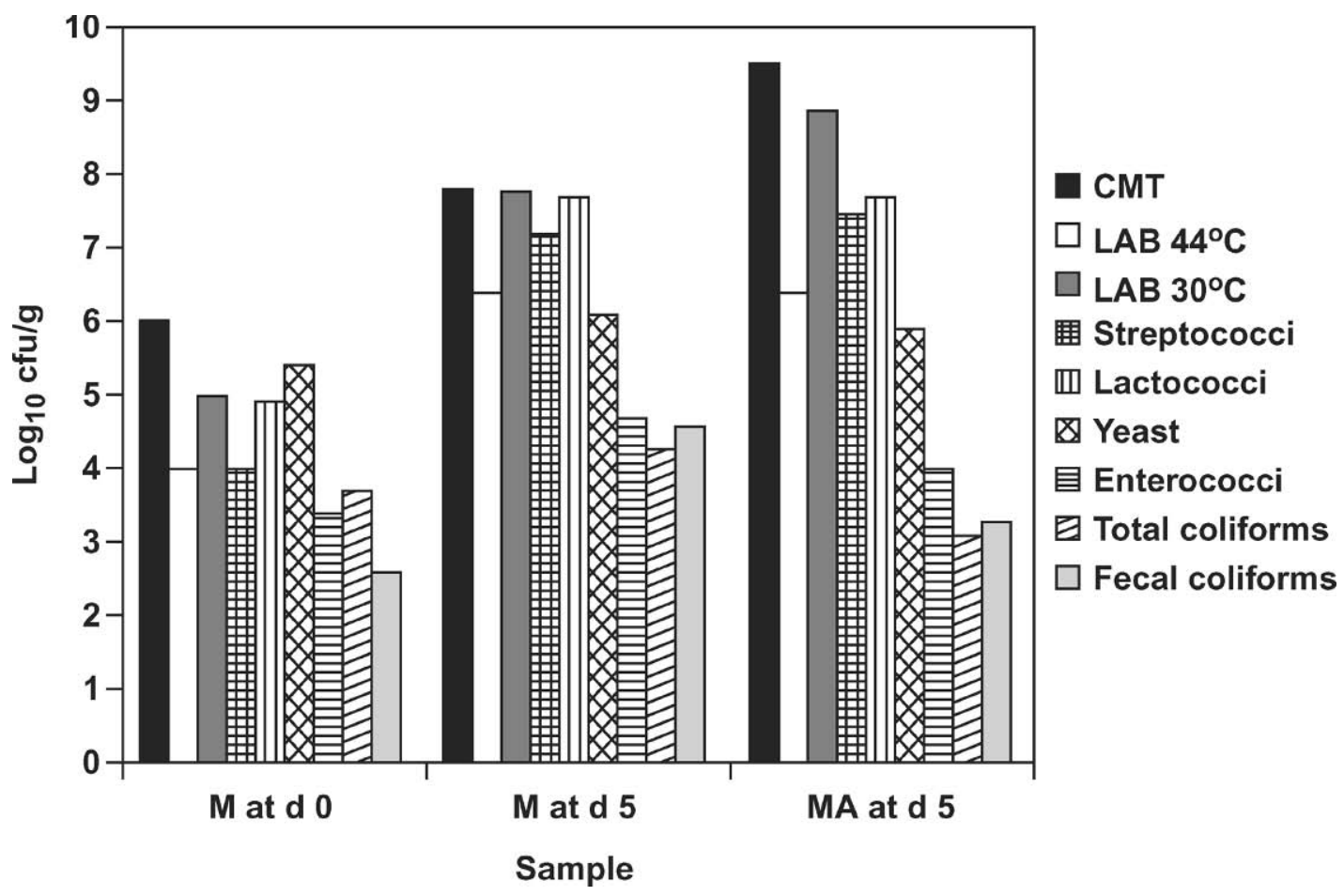

Figure 2. Microbial counts of water buffalo Mozzarella cheese at time 0 and stored at room temperature for $5 \mathrm{~d}$. M = water buffalo Mozzarella cheese stored in preservation liquid; MA = water buffalo Mozzarella cheese stored in innovative gel; CMT = total mesophilic microflora; LAB = lactic acid bacteria.

For the gel-stored cheese, the variations in $\mathrm{pH}$ were more regular, increasing regularly from $\mathrm{d} 0$ to 20 (from 5.25 to 5.60). The changes in $\mathrm{pH}$ during storage seemed to be closely related to the structure of Mozzarella, as reported in literature (Kindstedt et al., 2001; Guinee et al., 2002). In many studies, correlations among $\mathrm{pH}$, calcium content, and proteolysis of Mozzarella have been identified (Almena-Aliste et al., 2002; Jeremiah et al., 2003). In general, a $\mathrm{pH}$ reduction increases the ratio between soluble calcium and colloidal calcium,

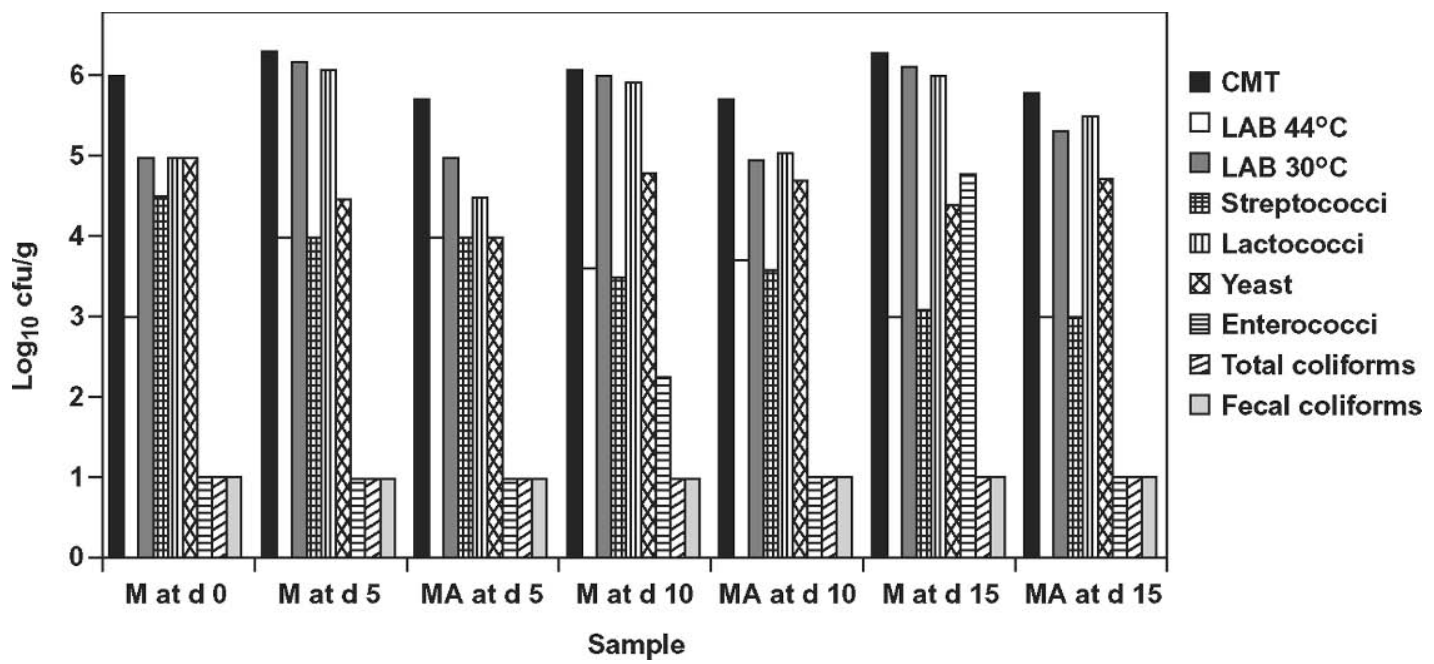

Figure 3. Microbial counts of water buffalo Mozzarella cheese at d 0 and stored at $4^{\circ} \mathrm{C}$ for 5,10 and 15 d. $\mathrm{M}=$ water buffalo Mozzarella cheese stored in preservation liquid; MA = water buffalo Mozzarella cheese stored in innovative gel; CMT = total mesophilic microflora; $\mathrm{LAB}=$ lactic acid bacteria. 
Table 1. pH of Mozzarella and storage media as measured at different times

\begin{tabular}{llllll}
\hline \multirow{2}{*}{$\begin{array}{l}\text { Time } \\
\text { d) }\end{array}$} & \multicolumn{2}{c}{ Mozzarella $^{1}$} & & $\begin{array}{l}\text { Preservation } \\
\text { liquid }\end{array}$ & Gel \\
\cline { 2 - 3 } & M & MA & & 4.28 & 7.23 \\
0 & 5.25 & 5.25 & 4.8 & 4.47 \\
5 & 5.31 & 5.35 & & 5.85 \\
10 & 5.42 & 5.58 & & 5.68 \\
20 & 5.02 & 5.6 & & 5.0 \\
\hline
\end{tabular}

${ }^{1} \mathrm{M}=$ Water buffalo Mozzarella cheese stored in preservation liquid; $\mathrm{MA}=$ water buffalo Mozzarella cheese stored in innovative gels.

which, in turn, would increase the degree of casein hydration (Sood et al., 1979) and reduce its aggregation state, ultimately increasing the susceptibility of casein to hydrolysis (Feeney et al., 2002). In the gel-stored Mozzarella, on the contrary, all $\mathrm{pH}$ values showed less variation from the initial values and they tended toward more alkaline values.

\section{Analysis of the Protein Fraction from Mozzarella Cheese}

To study the protein fraction included in Mozzarella cheese, the descriptive electrophoretic techniques currently used for monitoring casein hydrolysis in cheese (Addeo et al., 1995) were used. Figure 4 shows the isoelectric focusing profiles of the proteins extracted from samples of the same lot of water buffalo Mozzarella cheese after a storage at $8^{\circ} \mathrm{C}$ in its preservation liquid (lane b) or in gel (lane c) for $15 \mathrm{~d}$, and in its preservation liquid (lane d) or in gel (lane e) for $44 \mathrm{~d}$. These profiles were compared with those of proteins from a freshly produced cheese sample, kept at $20^{\circ} \mathrm{C}$ until the analysis (Figure 4, lane a). Disc-PAGE analysis of the whole protein fraction from the same Mozzarella cheese samples analyzed in Figure 4 is shown in Figure 5. For comparison, disc-PAGE analysis of proteins from a freshly produced cheese sample (lane a) and from a water buffalo whole casein sample (lane b) is also included. In order to detect even small differences in the electrophoretic profiles, $30 \mu \mathrm{g}$ of each protein sample was analyzed, instead of $20 \mu \mathrm{g}$, as suggested by Chianese et al. (1992). Nevertheless, the type and the extent of protein proteolysis, even after a 44-d storage period at $8^{\circ} \mathrm{C}$, were quite similar to those found in a freshly prepared sample, regardless of the environmental storage conditions (gel or liquid).

Moreover, no significant differences were detected among disc-PAGE electrophoretic profiles of the $\mathrm{pH}$ 4.6insoluble protein fractions from the same cheese samples or among SDS-PAGE electrophoretic patterns of the whole protein fractions (not shown). However, partial degradation of proteins generating small peptides,

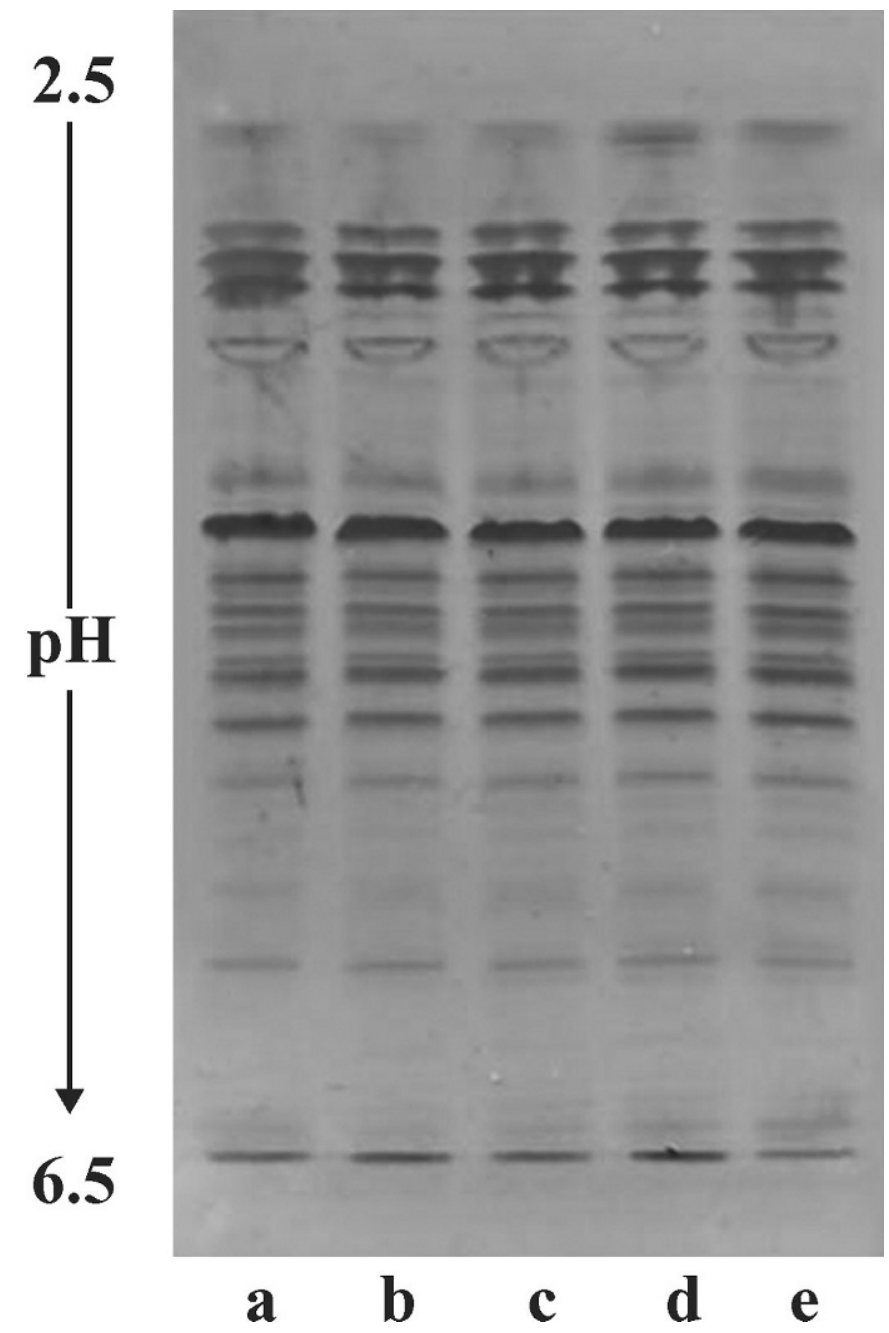

Figure 4. Isoelectric focusing-PAGE analysis of the whole protein fraction from water buffalo Mozzarella cheese samples stored at $8^{\circ} \mathrm{C}$ in its own liquid (lane b) or in gel (lane c) for $15 \mathrm{~d}$, and in its own liquid (lane d) or in gel (lane e) for $44 \mathrm{~d}$. The electrophoretic profile of a freshly produced cheese sample, kept at $-20^{\circ} \mathrm{C}$ until the analysis, is shown in lane a.

undetectable by electrophoretic techniques, cannot be excluded. According to previous studies, proteolysis occurring in Mozzarella cheeses at varying calcium contents and $\mathrm{pH}$ could be effectively evaluated by RPHPLC analysis of the $\mathrm{pH} 4.6$-soluble fraction (Feeney et al., 2002). In similar experimental conditions, the RP-HPLC chromatogram of the $\mathrm{pH} 4.6$-soluble fraction from a Mozzarella cheese sample stored at $8^{\circ} \mathrm{C}$ in gel (shown in Figure 6, panel B) was similar to that of the $\mathrm{pH}$ 4.6-soluble fraction from a cheese sample stored in its preservation liquid (panel C). In contrast, a clear difference was detected as regards the amount of the peptide eluting at 12 min (panel A) in RP-HPLC analysis of the $\mathrm{pH} 4$.6-soluble fraction from a freshly prepared 


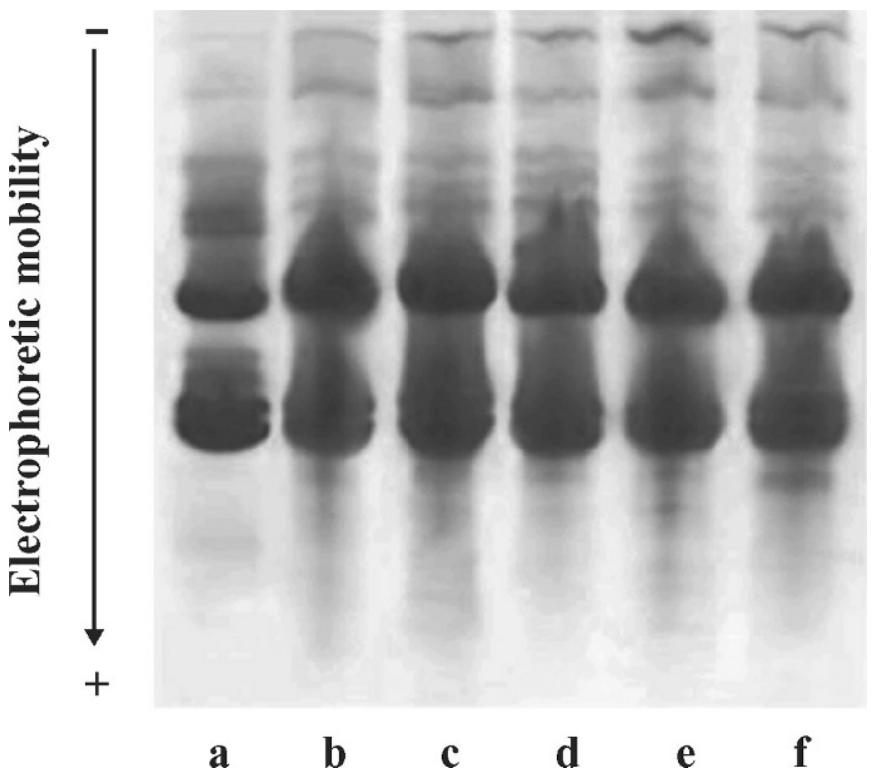

Figure 5. Disc-PAGE analysis of the whole protein fraction from water buffalo Mozzarella cheese samples stored at $8^{\circ} \mathrm{C}$ in gel (lane c) or in its own liquid (lane d) for $15 \mathrm{~d}$, and in gel (lane e) or in its own liquid (lane f) for $44 \mathrm{~d}$. The electrophoretic profiles of a freshly produced cheese sample and of a water buffalo whole casein sample, kept at $-20^{\circ} \mathrm{C}$ until the analysis, are reported in lanes a and b, respectively.

Mozzarella cheese sample. By comparing peak areas in RP-HPLC chromatograms acquired in triplicate, the average value relative to this peptide was similar in both cheese samples stored for $15 \mathrm{~d}$ at $8^{\circ} \mathrm{C}$, but 3.5 times lower than that determined in freshly prepared cheese.

\section{Mechanical Properties}

Physical properties are extremely important to evaluate the state of preservation of Mozzarella. Deformability, the resistance to break, and the compactness of a food during mastication, and the energy related to these operations, induce a pool of sensorial stimuli in the consumer, which contribute to the consumer's judgment on the quality of the food. We conducted tests to quantify the mechanical consistency of Mozzarella pasta as a function of the time and type of storage. Samples of Mozzarella (stored in liquid and gel) were compressed in monoaxial load by an Instron dynamometer to record the penetration force against the displacement. We carried out the above tests up to $30 \mathrm{~d}$ of storage and reported the results after 5 and $30 \mathrm{~d}$ of storage. After 5 $\mathrm{d}$, at which time the Mozzarella is still considered fresh, the control sample exhibited a strong diminution of compression strength, whereas the gel-stored sample maintained very high strength (Figure 7 ). The most impressive result was recorded after $30 \mathrm{~d}$ of storage
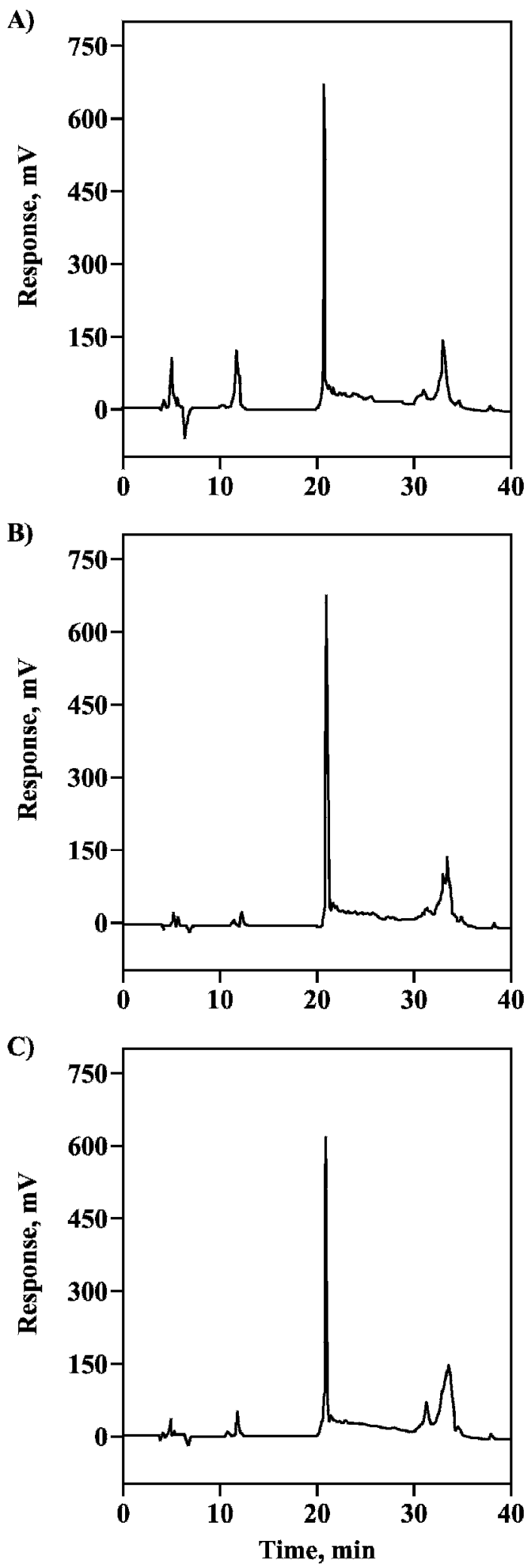

Figure 6. Reverse phase-HPLC of the $\mathrm{pH}$ 4.6-soluble fraction from a freshly prepared Mozzarella cheese sample (panel A), and from the same cheese stored for $15 \mathrm{~d}$ at $8^{\circ} \mathrm{C}$ in gel (panel B) or in its own liquid (panel C). 


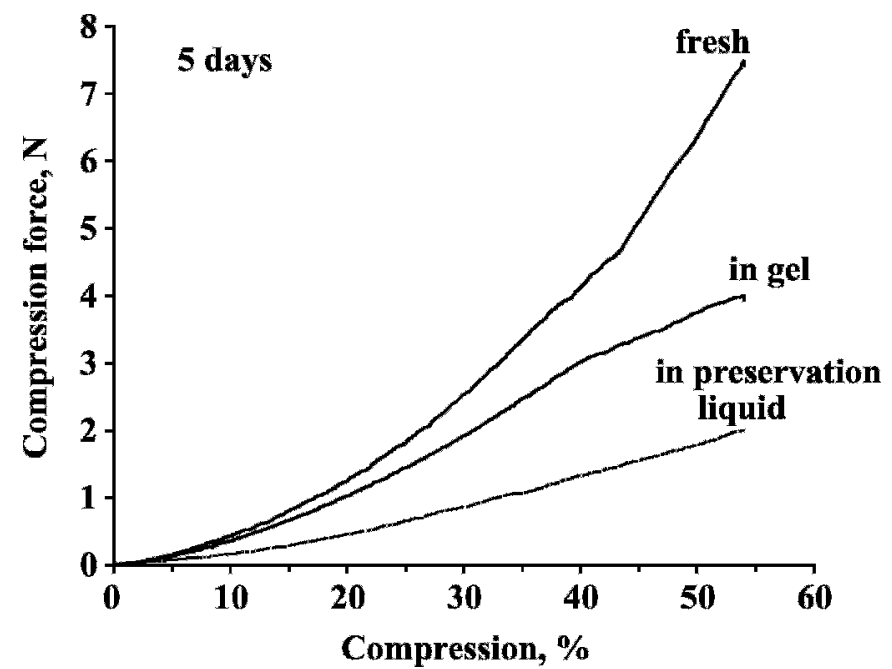

Figure 7. Compression tests of water buffalo Mozzarella stored for $5 \mathrm{~d}$ at $4^{\circ} \mathrm{C}$ in gel and in its own preservation liquid compared with fresh water buffalo Mozzarella cheese.

(Figure 8): the control sample reached a very low level of compressive strength, whereas the gel-stored cheese was essentially unchanged in mechanical strength.

\section{CONCLUSIONS}

The search for innovative packaging is a fundamental step in the strategy to save the characteristics of a typical product such as the water buffalo Mozzarella cheese. The development of packaging that would increase the shelf life of Mozzarella while preserving its

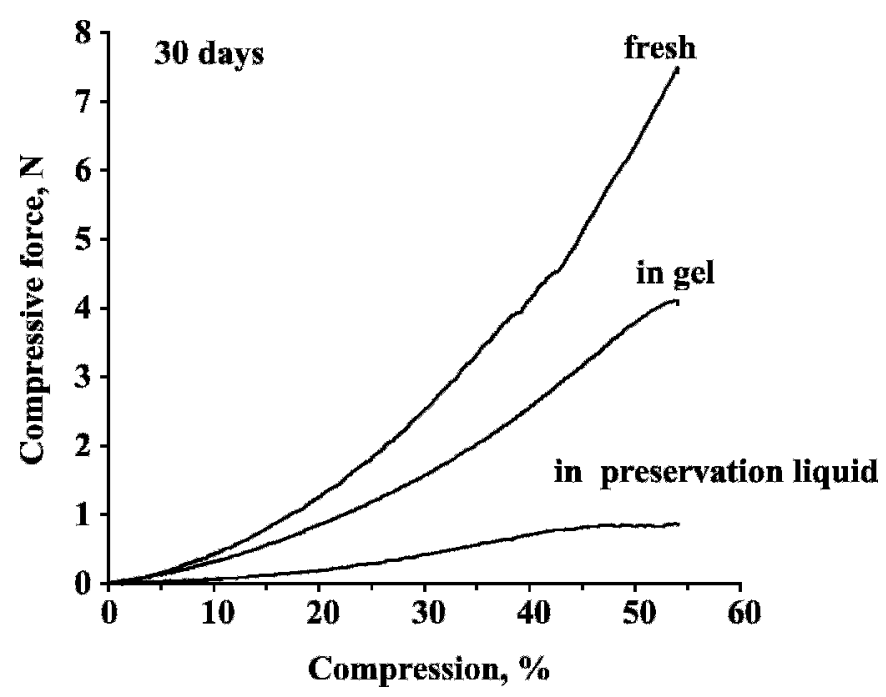

Figure 8. Compression tests of Mozzarella stored for $30 \mathrm{~d}$ at $4^{\circ} \mathrm{C}$ in gel and in its own preservation liquid compared with fresh water buffalo Mozzarella cheese. characteristic attributes would allow producers to reach markets currently unavailable due to distance and shipping costs. The innovative gels described in the present research, based on natural polysaccharides, allow the prolonged maintenance of sensorial properties of the cheese without the need for chemical or thermal treatment of the milk. We believe that the results, in part, are due to the controlled release of water from the gel to the Mozzarella, which regulates (slows down) the sensitivity of casein to water.

Our future research activity will concentrate on optimizing the gel properties and on the correlation between physicochemical, biochemical, and morphological properties to better understand the mechanisms that regulate the interesting effects reported herein.

\section{REFERENCES}

Addeo, F., G. Garro, N. Intorcia, L. Pellegrino, P. Resmini, and L. Chianese. 1995. Gel electrophoresis and immunoblotting for the detection of casein proteolysis in cheese. J. Dairy Res. 62:297-309.

Almena-Aliste, Q., M. Ge, and P. S. Kindstedt. 2002. Reversibility of $\mathrm{pH}$-induced changes in the calcium distribution and melting characteristics of Mozzarella cheese. Aust. J. Dairy Technol. 57:3-9.

Blakesley, R., and J. A. Boezi. 1977. A new staining technique for proteins in polyacrylamide gel using Coomassie Brilliant Blue G 250. Anal. Biochem. 22:580-582.

Chianese, L., R. Mauriello, L. Moio, N. Intorcia, and F. Addeo. 1992. Determination of ovine casein heterogeneity using gel electrophoresis and immunochemical techniques. J. Dairy Res. 59:39-47.

Coppola, S., E. Parente, S. Dumontet, and A. La Peccerella. 1988. The microflora of natural whey cultures utilized as starter in the manufacture of Mozzarella cheese from water-buffalo milk. Lait 68:295-310.

Coppola, S., F. Villani, R. Coppola, and E. Parente. 1990. Comparison of different starter systems for water-buffalo mozzarella cheese manufacture. Lait 70:411-423.

Ercolini, D., G. Mauriello, G. Blaiotta, G. Moschetti, and S. Coppola. 2004. PCR-DGGE fingerprints of microbial succession during a manufacture of traditional water buffalo mozzarella cheese. J. Appl. Microbiol. 96:263-270.

Feeney, E. P., T. P. Guinee, and P. F. Fox. 2002. Effect of $\mathrm{pH}$ and calcium concentration on proteolysis in Mozzarella cheese. J. Dairy Sci. 85:1646-1654.

Guinee, T. P., E. P. Feeney, M. A. E. Auty, and P. F. Fox. 2002. Effect of $\mathrm{pH}$ and calcium concentration on some textural and functional properties of Mozzarella cheese. J. Dairy Sci. 85:1655-1669.

Jeremiah, J. J., J. Sheehan, T. P. Timothy, and P. Guinee. 2003. Effect of $\mathrm{pH}$ and calcium level on the biochemical, textural and functional properties of reduced-fat Mozzarella cheese. Int. Dairy J. 14(Suppl. 2):161-172.

Kindstedt, P. S., A. M. Zielinski, Q. Almena-Aliste, and M. Ge. 2001. A post-manufacture method to evaluate the effect of $\mathrm{pH}$ on Mozzarella Cheese Characteristics. Aust. J. Dairy Technol. 56(Suppl. 3):202-207.

Masi, P., and F. Addeo. 1984. Caratteristiche reologiche di alcuni formaggi tipici a pasta filata. Il Latte IX:658-671.

Paonessa, A. 2004. Influence of the preservation liquid of Mozzarella di Bufala Campana D.O.P. on some aspects of its preservation. Bubalus bubalis IV:30-36.

Peterson, K., P. V. Nielsen, G. Bertelsen, M. Lawther, M. B. Olsen, N. H. Nilson, and G. Mortensen. 1999. Potential of biobased materials for food packaging. Trends Food Sci. Technol. 10:52-68. 
Pizzano, R., M. A. Nicolai, and F. Addeo. 1998. Antipeptide antibodies as analytical tools to discriminate among bovine $\alpha$ s 1 casein components. J. Agric. Food Chem. 46:766-771.

Robertson, G. L. 1993. Packaging of dairy products. Pages 507-550 in Food Packaging: Principles and Practice. Marcel Dekker, New York, NY.

Salvatori del Prato, O. 1998. La pasta filata. Pages 588-632 in Trattato di tecnologia casearia. Vol. 17. Edagricole, Bologna, Italy.
Sood, V. K., D. K. Gaind, and R. K. Dewan. 1979. Correlation between micelle salvation and calcium content. N.Z. J. Dairy Sci. Technol. 14:32-34.

Trieu-Cuot, P., and J. C. Gripon. 1981. Isoelectric focusing and two dimensional electrophoresis of bovine caseins. J. Dairy Res. 48:303-310

Vernon, E. J., and P. Sherman. 1978. Evaluation of the firmness of Leicester cheese by compression tests with the Instron Universal Testing Machine. J. Texture Stud. 9:311-318. 